\title{
Lepadarg

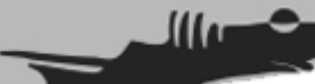

CIBERARQUEOLOGIA: O DIÁLOGO ENTRE REALIDADE VIRTUAL E ARQUEOLOGIA NO DESENVOLVIMENTO DE VIPASCA ANTIGA Cyber-Archaeology: dialoguing Virtual Reality and Archaeology in the development of Vipasca Antiga 


\title{
Ciberarqueologia: o diálogo entre realidade virtual e arqueologia no desenvolvimento de Vipasca antiga
}

\begin{abstract}
Alex da Silva Martire ${ }^{1}$
Resumo: Este artigo apresenta os conceitos principais que estão relacionados à área da Ciberarqueologia: um ramo recente dentro da Arqueologia que estabelece o diálogo entre Realidade Virtual e os trabalhos arqueológicos. Primeiramente é apresentado o panorama da história da cibernética a fim de contextualizar a Realidade Virtual. Depois são discutidas as definições de real e virtual. Por fim, é apresentada a prática ciberarqueológica, ou seja, o diálogo entre cibernética e arqueologia, por meio do aplicativo Vipasca Antiga, um simulador interativo sobre uma antiga área de mineração romana hoje pertencente ao território de Portugal, e produto final da pesquisa de Doutorado do autor deste artigo.

Palavras-chave: Realidade Virtual; Interatividade; Roma Antiga; Mineração.
\end{abstract}

\begin{abstract}
This article presents the main concepts that are related to Cyber-Archaeology: a recent development within archaeology that establishes a dialogue between Virtual Reality and archaeological works. First an overview of the history of cybernetics is presented in order to contextualize Virtual Reality. Then the real and virtual definitions are discussed. Finally, the cyberarchaeological practice (i.e. the dialogue between cybernetics and archeology) is presented through the Vipasca Antiga application: an interactive simulator about an ancient Roman mining area now belonging to the territory of Portugal, and the final product of my PhD research.
\end{abstract}

Keywords: Cyber-Archaeology; Virtual Reality; Interactivity; Ancient Rome; Mining.

\section{INTRODUÇÃO}

Todas as vezes em que disse a um colega arqueólogo que estudo Ciberarqueologia eu recebi um olhar curioso como resposta. Geralmente não ouviram falar sobre isso antes e, para mim, é compreensível, afinal, é uma ramificação recente dentro da arqueologia, tendo aparecido mais na mídia após 2010, com a publicação do volume da coleção BAR International Series denominado Cyber-Archaeology, editado por Maurizio Forte. Eu mesmo só comecei a trabalhar com Ciberarqueologia em 2012, quando ingressei no programa de pós-graduação para desenvolver minha pesquisa de Doutorado. De lá para cá, tenho acompanhado, sempre com entusiasmo, notícias pululando em revistas especializadas em arqueologia, vídeos no YouTube e/ou Facebook, e publicações em meios digitais (por exemplo, a Virtual Archaeology Review ${ }^{2}$ ). Muitas vezes, o nome "Ciberarqueologia" sequer está relacionado ao objeto em questão, mas, creia-me, a arqueologia cibernética está ali presente.

Para ser sincero, acredito que muitos praticam a Ciberarqueologia, mas poucos realmente pararam para aprofundar seus conhecimentos sobre o tema: quando isto acontece, geralmente vemos

\footnotetext{
${ }^{1}$ Doutor em Arqueologia pelo Museu de Arqueologia e Etnologia da Universidade de São Paulo (MAE-USP), Brasil; Pesquisador no Laboratório de Arqueologia Romana Provincial da Universidade de São Paulo (LARP-USP), Brasil.

2 Pode ser acessada em: http://polipapers.upv.es/index.php/var (Acesso em 29/03/2017)
} 
terminologias como "Arqueologia Virtual" ou "Arqueologia Digital" aparecendo em artigos ou notícias. A Ciberarqueologia, como tentarei mostrar neste artigo, é uma temática complexa, é uma relação íntima entre cibernética (no caso, a Realidade Virtual) e arqueologia. Dizer que Ciberarqueologia é o uso de computadores na arqueologia porque tem o prefixo "ciber" em seu nome é simplificar demais a questão. A cibernética é uma área de estudos surgida com a publicação de Cybernetics: or control and communication in the animal and the machine, do matemático estadunidense Norbert Wiener, em 1948, e ainda muito atuante (na verdade, tão atuante que, para redigir este artigo em meu computador, eu dependo quase que exclusivamente dela).

Para iniciar este artigo, então, irei discorrer brevemente sobre cibernética trazendo um panorama de seu desenvolvimento. Quando chegar na Realidade Virtual dentro desse histórico, irei apontar a diferença entre real e virtual com base nas ideias do filósofo Pierre Lévy e falarei sobre os dois eixos fundamentais da Realidade Virtual: a imersão e a interatividade. As discussões anteriores servirão para dar suporte à definição de Ciberarqueologia (e dizer o porquê de ela ser diferente da Arqueologia Virtual). Por fim, citarei como exemplo o trabalho ciberarqueológico realizado durante meu Doutorado, o aplicativo Vipasca Antiga: um programa de computador que permite ao usuário interagir em tempo real com a paisagem histórico-arqueológica da antiga zona mineradora romana denominada Vipasca (uma das maiores produtoras de cobre do Império Romano, que atualmente está na cidade de Aljustrel, no sul de Portugal). Vipasca Antiga é o primeiro trabalho interativo ciberarqueológico sobre a mineração romana na antiga Lusitânia, sendo, assim, pioneiro na área da aplicação de Realidade Virtual aos estudos sobre a região. 0 aplicativo Vipasca Antiga pode ser baixado no endereço: www.vipasca.com.

\section{UMA HISTÓRIA CIBERNÉTICA}

Seguindo a subdivisão feita pela crítica literária pós-moderna N. Katherine Hayles (1999), a Cibernética teve três ondas de pesquisas com eixos centrais, ou seja, três momentos em que a sua definição variou, seguindo modelos propostos por pesquisadores expoentes na área. A Primeira Onda durou de 1945 até 1960, e foi marcada pelo conceito central de homeostase, ou seja, a autorregulação de um sistema a fim de estar sempre em equilíbrio. Essa onda surgiu a partir de trabalhos apresentados na primeira Macy Conference on Cybernetics (1946) em Nova York. Um dos trabalhos mais relevantes dessa conferência foi apresentado pelo matemático estadunidense Norbert Wiener, apregoando que, na relação homem-máquina, a entidade mais importante para o estudo não era a energia, mas, sim, a informação. A fim de aprofundar essa temática, Wiener publicou, em 1948, o livro Cibernética e Sociedade. 0 uso humano de seres humanos. Nele, o matemático discorre sobre como a linguagem dos homens pode ser aplicada às máquinas. Wiener começa dizendo que cunhou o termo cibernética para abarcar suas ideias e que a 
palavra deriva do termo grego kubernetes, ou seja, piloto, timoneiro dos navios; aquele que regula a todo instante o percurso no mar.

A importância dessa homeostase dentro da cibernética ficou ainda mais evidenciada com o dispositivo criado, em 1948, pelo psiquiatra inglês W. Ross Ashby no Barnwood House Hospital (Gloucester, Inglaterra), o homeostato: um dispositivo eletrônico construído com transdutores (dispositivos eletrônicos que transformam um sinal de entrada em outro; por exemplo, uma antena de televisor) e potenciômetros (resistores reguláveis). Ao receber um sinal de entrada que mudasse seu estado prévio, o aparelho buscava por uma configuração de variáveis que pudessem retorná-lo à condição inicial. O homeostato é muito semelhante ao estabilizador conectado ao seu computador: a sua função é regular a entrada de energia, controlando os picos de tensão a fim de sempre manter a saída de alimentação constante em 110 ou 220V. Com seu aparelho, W. Ross Ashby reforçou as ideias em voga de que: 1) os humanos são mecanismos que respondem a seus ambientes tentando manter a homeostase; 2) a restrição para se criar máquinas inteligentes reside em formular os problemas de modo correto; e 3) um conceito de informação que privilegia a exatidão sobre o significado serve melhor a um modelo de construção do que um conceito de informação impreciso (HAYLES, 1999, p. 67).

Ressalta-se, porém, que, em nenhum momento, esses primeiros estudos cibernéticos levaram em consideração o conteúdo presente na informação; apenas interessava o modo como a informação era transmitida. O desejo de incluir o observador dentro do sistema regulável levou ao surgimento da Segunda Onda cibernética (1960 - 1985). Os principais pesquisadores dessa onda foram os biólogos Humberto Maturana e Francisco Varela, que trouxeram à literatura o termo autopoiese ("criação própria", em grego), significando sistemas que conseguem reproduzir a si mesmos (por exemplo, o metabolismo celular, em que os componentes de uma célula produzem outros componentes que, por sua vez, fazem parte de uma intricada rede conectada). A autopoiese de Maturana e Varela adicionou à cibernética a ideia de reflexividade, ou seja, o mundo que observamos só existe como tal a partir do momento em que levamos em consideração as experiências próprias do observador - experiências essas que modelam a forma como o organismo enxerga o seu redor (MATURANA E VARELA, 2011). Em outras palavras, o conteúdo da informação é fundamental dentro de uma comunicação existente em um sistema.

A Terceira Onda cibernética, por sua vez, surgiu por volta de 1980, e dura até os dias de hoje. Três são as principais correntes de estudos dessa onda: a Vida Artificial, a Inteligência Artificial e a Realidade Virtual. A Vida Artificial (V. A.) surgiu na década de 1980 com os trabalhos do cientista da computação estadunidense Christopher G. Langton, e propunha uma visão analítica oposta à da Biologia: ao invés de começar os estudos pelo topo - enxergando o organismo como uma complexa máquina biomecânica - e seguir até a base (órgãos, tecidos, células, organelas, membranas e moléculas) em busca dos mecanismos da vida, a V. A. começa da base - enxergando o organismo como uma grande população de máquinas 
simples - e segue a análise até o topo, "construindo enormes agregados de simples e regulados objetos que interagem uns com os outros não-linearmente no apoio de dinâmicas globais" (LANGTON 1988, p. 2). Já a Inteligência Artificial (I. A.) busca solucionar o teste proposto por Alan Turing em seu artigo "Computing Machinery and Intelligence", publicado na revista Mind (1950). Projetado por Turing - e até hoje não solucionado - o teste visava a fornecer uma definição operacional satisfatória de inteligência: basicamente, trata-se de um homem separado de um computador por meio de uma parede; o computador passará no teste de inteligência humana se o interrogador humano, depois de propor algumas questões por escrito, não conseguir distinguir se as respostas escritas obtidas são de outra pessoa ou de um computador. Para conseguir tal feito, os computadores deveriam, segundo Turing, ter as seguintes características (NORVIG E RUSSEL, 2014): processamento de linguagem natural - permitindo ao computador a comunicação em um idioma natural com sucesso; representação de conhecimento - ou seja, armazenar o que se sabe ou ouve; raciocínio automatizado - uso das informações armazenadas para responder questões e obter novas conclusões; aprendizado de máquina - a fim de se adaptar a novas circunstâncias e detectar e extrapolar padrões.

Antes de aprofundar a temática da Realidade Virtual presente na terceira onda cibernética, é necessário explanar as duas palavras que compõe o termo: a realidade e o virtual.

\section{VIRTUALIZANDO A REALIDADE}

Para definir o que é real, tomarei por base as ideias propostas pelo filósofo Pierre Lévy em sua obra O que é o virtual?, publicada na França em 1995. Para fins didáticos, podemos separar em três definições principais que norteiam seu pensamento:

1) Real: é aquilo que existe no momento, é o presente. Seguindo o exemplo proposto por Lévy em seu livro, o real é como uma árvore que enxergamos.

2) Virtual (do latim virtus, "força, potência"): é o potencial de algo vir a ser real, embora o virtual em si seja real. Dentro da semente está uma árvore em potencial, a semente é o virtual da árvore e, como semente, é real também. Uma árvore pode, do mesmo modo, vir a ser uma folha de papel, logo, a árvore também contém o virtual, mesmo sendo real. A virtualização é um questionamento, é uma problemática que deve ser respondida em algum momento.

3) Atual: é o que algo é de fato, é uma espécie de "codificação". O atual da árvore é ser madeira, seiva, galhos, raízes e folhas. A atualização, então, se opõe não ao real, mas ao virtual, uma vez que fornece respostas às problemáticas geradas pela virtualização. Assim sendo, a virtualidade e atualidade são dois tipos diferentes da realidade. 
Em outras palavras: tudo é real! Podemos tomar como exemplo, também, um arquivo de texto em um programa de computador. $O$ real é o ato de interagir com o computador para que caracteres surjam na tela; quando salvamos esse arquivo, ele se torna virtual, pois está armazenado na máquina e poderá voltar a ser real quando retomar a redação. Já o processo de codificação/decodificação de bits e bytes que tornará o arquivo armazenado em caracteres na tela para retomar a redação é o atual, pois a todo instante o real se atualiza.

Se fui bem-sucedido nas explicações acima, agora ficou claro a você que Realidade Virtual (R. V.) não é uma "realidade falsa", pois "virtual" não é sinônimo de algo que não existe. Realidade Virtual é, sim, uma realidade em potencial, ou seja, algo que pode vir a ser (ou poderia ter sido) real. No caso do uso de $\mathrm{R}$. V. para simulações arqueológicas, sempre é empregada no sentido de "um passado que poderia ter sido assim". Uma vez que nós arqueólogos trabalhamos com hipóteses, toda a R. V. arqueológica será, também, um campo de testes, utilizando computadores para gerar modelos tridimensionais sobre aquilo que pensamos que pode ter existido em algum ponto do passado.

A R. V. surgiu como área de pesquisa no contexto da Segunda Guerra Mundial, quando, em 1940, os EUA desenvolveram simuladores de voo para treinar seus pilotos em combate. $\mathrm{O}$ aparato consistia em uma cabine de tiros semelhante à encontrada nos aviões da época e uma tela grande: os soldados entravam na cabine e um filme com aviões inimigos era mostrado na tela - dispositivos integrados ao sistema reconheciam em quais lugares os soldados estavam atirando para detectarem se acertavam ou não os inimigos. Esses simuladores apresentaram os dois conceitos fundamentais que até hoje estão no cerne da R. V., a imersão (o usuário se sentia em uma aeronave) e a interatividade em tempo real (a resposta sobre aviões abatidos).

A imersão é um tópico que depende demais da subjetividade. Quantas vezes você já não ficou "perdido em pensamentos" enquanto assistia a um filme ou jogava videogame? Estar imerso é sentir-se presente, mas, convenhamos, é dificílimo definir o que é presença. Proponho que deixe este artigo de lado agora e pense consigo mesmo sobre as seguintes questões: como você prova que está presente? 0 que o torna um ser imbuído de presença neste mundo? Presença é sinônimo de raciocínio? Os questionamentos são complexos e devem ser levados em conta quando os desenvolvedores de R. V. trabalham em um projeto: muito provavelmente nem todos os usuários terão a imersão pretendida inicialmente. Para auxiliar, podemos desenvolver produtos que funcionem em H. M. D. (Head-Mounted Display, "vídeocapacete estereoscópico"), ou seja, óculos de R. V. (tal como o Oculus Rift, por exemplo): esses capacetes cobrem a visão do mundo exterior e geram no usuário a sensação de que ele está rodeado por um mundo virtual. Embora estejam cada vez mais acessíveis economicamente, os óculos de R. V. ainda são novidade e poucos usuários os possuem. Desse modo, a maioria das aplicações acaba utilizando monitores de computadores ou televisores para projetar conteúdo. Sei que pode parecer estranho comparar um simples 
monitor com um capacete de visão $360^{\circ}$, mas lembre-se que, muitas vezes, você se sentiu na pele do protagonista daquele seu jogo favorito utilizando uma tela plana (ou curva, se você tiver a minha idade e conheceu as "TVs de tubo").

A interatividade, por sua vez, é aquilo que diferencia os filmes dos jogos. Embora eu adore assistir a filmes de época nas sessões do projeto Pipoca Clássica (LECA/UFPel), admito que não tenho o poder de modificar a história, de intervir na situação apresentada: filmes não permitem isso, são mídias nãointerativas. Nos jogos, porém, incorporo uma personagem e a movimento pelo ambiente digital. Posso correr, nadar, falar com outras personagens, roubar itens, brigar, explodir coisas... enfim, quase tudo o que faço na minha vida. Os jogos eletrônicos, principalmente, permitem que eu interaja em tempo real, e toda a minha interação é comunicada ao computador, que retorna minhas informações com atualizações: ou seja, a interação em tempo real é cibernética, como já vimos. Para interagir, posso utilizar dispositivos que se tornam extensão de meu corpo: teclado, mouse, gamepad, sensores de movimento - só para citar alguns. No momento da interação, então, existe uma simbiose entre homem e máquina: minhas ações são levadas ao computador por meio de inputs (dispositivos físicos) e, após decodificadas, elas são apresentadas na tela (ou capacete) em forma de reação: uma constante retroalimentação (feedback).

Creio que, após a apresentação de todas essas conceituações, está na hora de pormenorizar o que, de fato, é a Ciberarqueologia, e como ela está ligada a tudo isso o que foi dito até aqui.

\section{CIBERARQUEOLOGIA}

A aplicação de modelos tridimensionais na Arqueologia não é novidade, sendo que seu uso acompanha a própria evolução gráfica computacional, surgindo nos anos 1980. Contudo, em 1990, o cientista da computação Paul Reilly publicou um artigo que, de fato, despertou parte da comunidade científica arqueológica para o tema da computação gráfica (REILLY, 1990), propondo que o registro arqueológico vá além daquele feito em papel: utilizando computadores podemos reconstituir etapas de escavações com seus contextos originais, propiciando melhor entendimento sobre o trabalho realizado.

A arqueologia computacional proposta por Reilly, a qual denominamos Arqueologia Virtual, contudo, era baseada em simulações renderizadas, ou seja, modelos tridimensionais que são vistos em filmes, não em tempo real. Ainda hoje podemos ver a Arqueologia Virtual atuando: basta irmos a uma exposição com telas passando animações computadorizadas, ou então sintonizarmos em canais a cabo para vermos belíssimas reconstituições tridimensionais surgirem no televisor. Deixo claro que não tenho nada contra a Arqueologia Virtual, pois entendo que determinadas situações ou mídias requerem apenas animações renderizadas. Contudo, o próprio processo cognitivo é afetado nessas ocasiões: você se sentiria mais parte, digamos, de uma cidade grega vendo um filme sobre pessoas caminhando nas ruas ou você 
sendo o transeunte e podendo ir para o local que escolher? É justamente isso que a Ciberarqueologia propõe.

Se a Arqueologia Virtual pode ser comparada ao cinema, a Ciberarqueologia tem como modelo os jogos eletrônicos. O termo foi apresentado pelo arqueólogo Maurizio Forte em 2010, quando foi publicado o volume da coleção BAR International Series denominado Cyber-Archaeology. A Ciberarqueologia é uma junção dos termos "ciber" com "arqueologia", por isso, podemos dizer que a cibernética é parte essencial da Ciberarqueologia. O prefixo "ciber" denota a existência de retroalimentação em um sistema homemmáquina, sendo que a comunicação entre ambos acontece por meio da Realidade Virtual.

A Ciberarqueologia pertence ao contexto digital no qual estamos inseridos atualmente. Podemos dizer que até os anos 1990 a Arqueologia era essencialmente analógica. Todos os registros em campo eram feitos principalmente em papel, sendo que até mesmo as fotografias eram realizadas por câmeras analógicas que necessitavam ter os filmes revelados (e dependiam muito das habilidades do fotógrafo, pois não era possível ver em tempo real o resultado da imagem quando apertava-se o botão de disparo). Os mapas - embora o uso de computadores já estivesse mais difundido - também eram, em sua maioria, produzidos em materiais "palpáveis", sobrepondo-se folhas de papel para visualizar cada camada (layer) de informação. Porém, o avanço da microeletrônica fez com que os microcomputadores se tornassem mais acessíveis devido à queda de custo no desenvolvimento e produção de componentes eletrônicos e, a partir dos anos 2000, a aquisição de computadores para uso doméstico teve crescimento acelerado. Essa mudança no consumo refletiu-se na produção acadêmica também: agora se tornava mais fácil produzir material digital em casa ou nos laboratórios. Os mapas, antes "analógicos", ganharam mais facilidade de produção e transporte devido ao uso de SIGs (Sistemas de Informação Geográficas) que, atuando somente no campo digital, facilitaram a inserção de maior quantidade de dados em cada camada pois não se limitava mais ao espaço físico de uma folha de papel. Do mesmo modo, as câmeras fotográficas digitais permitiram ver, em campo, os resultados das fotografias e a edição posterior em computadores a fim de melhorar a visualização de informações (ou gerar modelos 3D por meio de fotogrametrias). Hoje também é possível levar tablets para o local da escavação e fazer todo o registro digitalmente, salvando os dados em nuvem computacional para que sejam acessados em tempo real por outros pesquisadores. Os escâneres 3D, por sua vez, tornaram-se parte relevante na Ciberarqueologia: as nuvens de pontos obtidas de sítios ou artefatos são convertidas em modelos tridimensionais que podem ser impressos ou trabalhados em motores gráficos para serem visualizados pelos usuários em Realidade Virtual. Por fim, a partir de 2014 vimos um enorme boom no desenvolvimento de óculos imersivos de R. V. a preços acessíveis, principalmente com a chegada do Oculus Rift ao mercado: a maioria dos motores gráficos de jogos atualmente fornece suporte a dispositivos de alta imersão. 
A Ciberarqueologia pode ser estudada e aplicada na prática em duas categorias (MARTIRE, 2017, p. 109-110):

1) Coleta de dados no campo (com dispositivos que transformam as informações em meio digital), e visualização científica tridimensional em laboratório a fim de se analisar o que está sendo escavado (e, posteriormente, todo o conjunto de dados obtidos). Por exemplo, trabalhos que são desenvolvidos em Çatalhöyük, na Turquia, onde cada etapa da escavação é registrada tridimensionalmente para servir como reconstituição do sítio (que, ainda hoje, é um processo bidimensional, centrado em relatórios de campo, desenhos de estratigrafias/vestígios, e fotografias);

2) Divulgação de resultados e/ou como recurso didático-educativo. Desenvolvimento de aplicativos e programas que façam a interação entre usuário (seja ele arqueólogo ou público em geral) e ambientes virtuais tridimensionais. Assim, são mostrados todos os resultados oriundos das pesquisas anteriores e ocorre a multivocalidade, onde todas as pessoas podem opinar e trabalhar juntas para melhorar a experiência imersiva digital realizada por meio de computadores.

O aplicativo ciberarqueológico Vipasca Antiga desenvolvido durante minha pesquisa de Doutorado, e objeto central deste artigo, pertence à segunda categoria.

\section{VIPASCA ANTIGA: CIBERARQUEOLOGIA NA PRÁTICA}

Vipasca foi o nome dado a uma área de mineração de cobre no Império Romano que hoje está localizada na vila de Aljustrel, no distrito de Beja, sul de Portugal. Aljustrel está localizada, geologicamente, sobre a Faixa Piritosa Ibérica (FPI): conjunto de grandes depósitos de sulfetos polimetálicos e maciços de manganês que se estende desde a mina de Las Cruces (Sevilha, Espanha), até a mina da Caveira (Grândola, Portugal). De origem vulcano-sedimentar, a formação de sulfetos de ferro teve lugar em águas profundas sem movimento, impedindo a renovação do oxigênio. Os elementos principais dos sulfetos são o enxofre e o ferro, que atingem cerca de $91 \%$ da massa mineral da FPI. No caso de Aljustrel, em todas as massas predomina mais o zinco (5,51\%) do que o cobre (1,67\%) (PÉREZ MACíAS et al. 2013, p. 6-10). A mineração em Aljustrel se faz presente desde o IIIo Milênio a. C., mas somente sob a dominação romana (por volta dos séculos I e IV d. C.) a região começou a produzir em escala industrial. Conhecida pelo nome pré-romano de Vipasca, o território foi um importante vicus (aldeia, em latim) dentro da cidade de Pax lulia (atual Beja).

Para fins didáticos, irei apresentar agora apenas as principais características da paisagem antiga de Vipasca juntamente com seus correlatos tridimensionais usados no aplicativo Vipasca Antiga. Gostaria de ressaltar que o processo de desenvolvimento contou com a consultoria de Artur Martins, arqueólogo e diretor do Museu de Aljustrel, reconhecido especialista português no campo da mineração na Antiguidade. 


\section{Terreno}

Embora o Alentejo (região do centro-sul de Portugal onde Aljustrel está localizada) seja formada predominantemente por planícies, quem visita Aljustrel hoje em dia irá notar que, da base do chapéu de ferro (ou seja, zona de oxidação de sulfetos), estende-se uma colina que desce até a Ribeira (ou ribeirão) de Feitais, sendo todo esse espaço pertencente à atual empresa mineradora da região (Fig. 1). Assim sendo, temos na paisagem três importantes marcos: o chapéu de ferro no ponto mais alto, a colina e a ribeira. Essas características foram pensadas em ser destaque no aplicativo tridimensional.

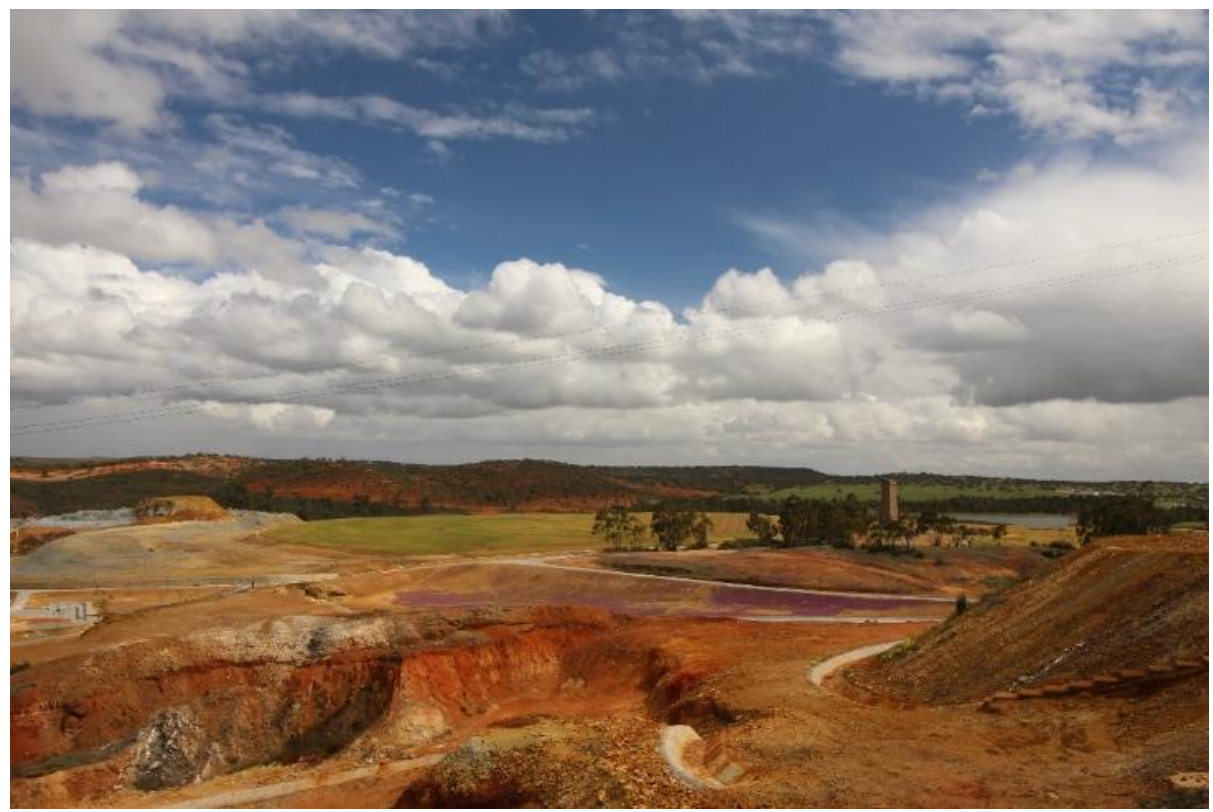

Figura 01: Vista da Casa do Procurador a partir da base do chapéu de ferro: notar o sentido descendente.

O modelo tridimensional do terreno foi esculpido diretamente no motor gráfico (ou seja, um programa próprio para a criação de interatividades em tempo real utilizando programação orientada a objetos e renderização de modelos 2D ou 3D) para jogos denominado Unity ${ }^{3}$. Para facilitar a composição das nuances do terreno (por exemplo, irregularidades), partiu-se da base fornecida pelo criador de relevos denominado Gaia4". Com ele, foi estabelecido um terreno com resoluções de 2048 unidades de comprimento por 2048 unidades de largura e 600 unidades de altura (sendo cada unidade do Unity equivalente a 1 metro). Todo o esculpimento digital e a texturização do terreno levou cerca de quatro semanas para ser finalizado. Destaca-se também o fato de o chapéu de ferro não ter a forma que se observa hoje em dia (praticamente desmontado em sua totalidade) (Fig. 2): como o aplicativo está balizado no século II d. C., o chapéu de ferro ainda não havia sido explorado em demasia pelos romanos. A forma final do terreno tridimensional está apresentada nas Figs. 3-4.

\footnotetext{
${ }^{3}$ www.unity.com

${ }^{4}$ www.assetstore.unity3d.com/en/\#!/content/42618
} 


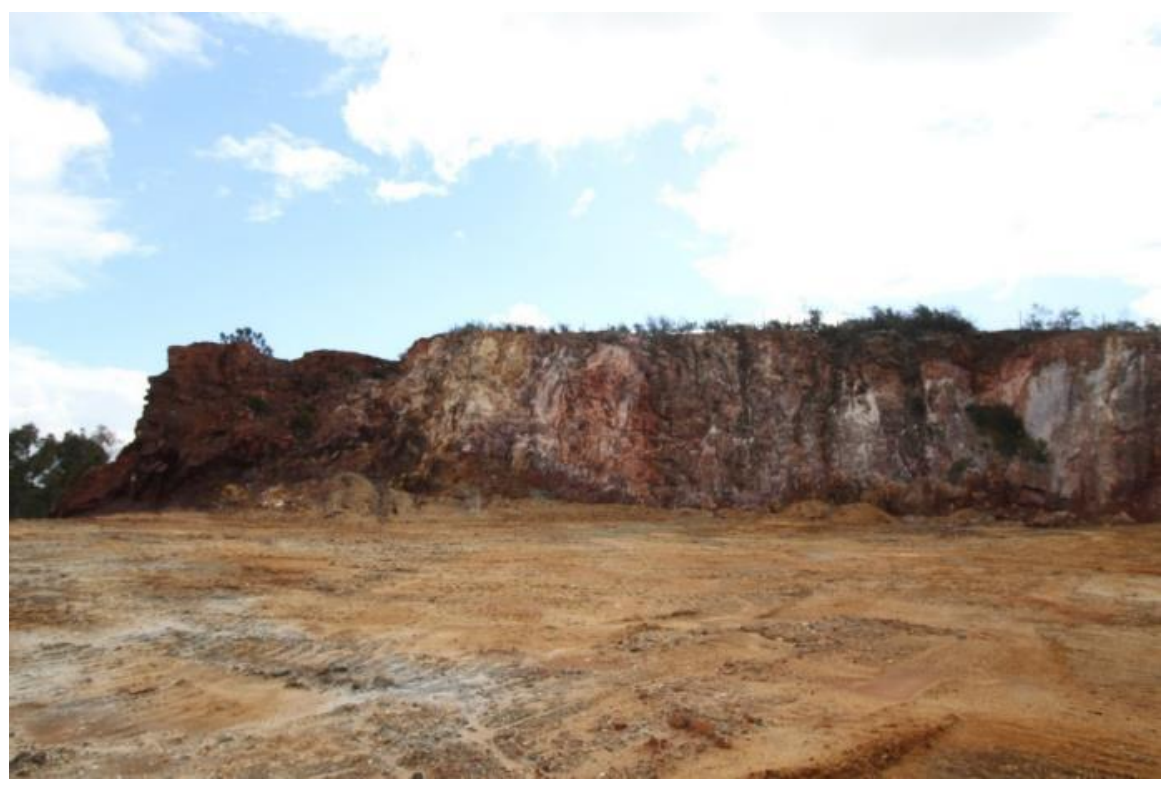

Figura 02: Chapéu de ferro explorado pelos romanos em Aljustrel.

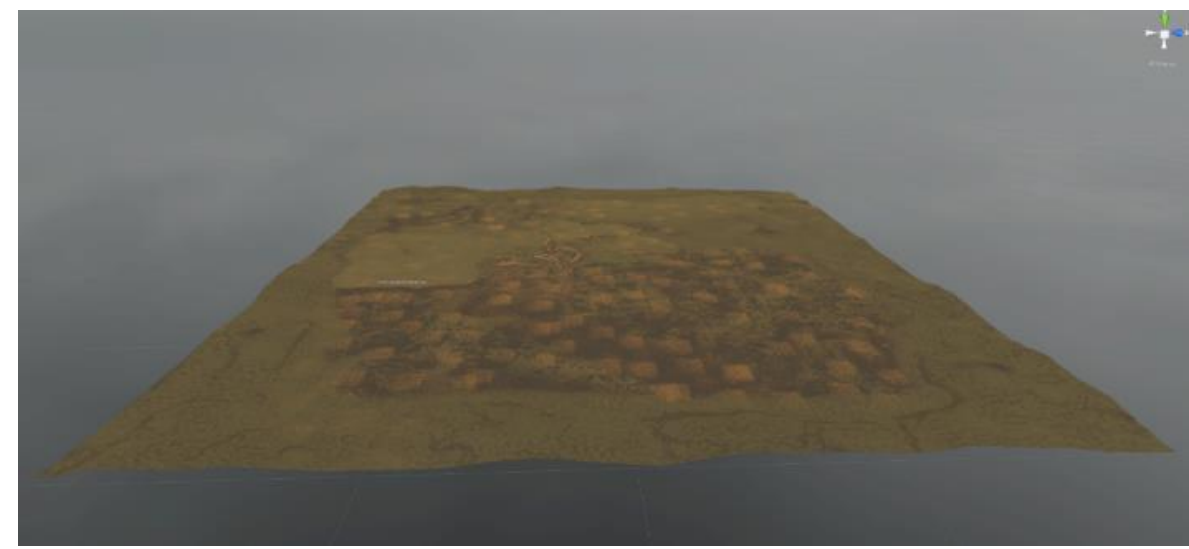

Figura 03: Terreno em perspectiva. Captura de tela dentro do motor gráfico Unity.

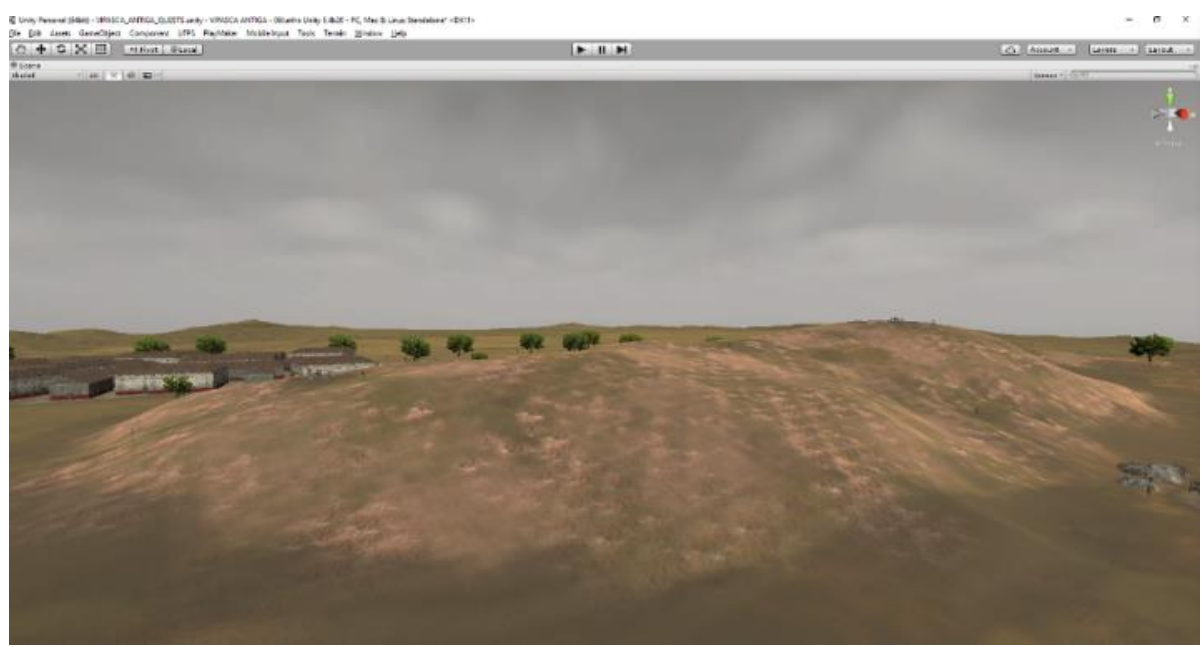

Figura 04: Vista da versão final do chapéu de ferro com sua coloração típica destoante na paisagem. Captura de tela dentro do motor gráfico Unity. 


\section{Casa do Procurador}

A Casa do Procurador é uma domus localizada na área de Algares, em Aljustrel. Tendo sido posta à luz no século XIX e depois estudada cuidadosamente no século XXI, as escavações revelaram tratar-se de um edifício de peristilo central rodeado por compartimentos (Fig. 5). Os vestígios encontrados na casa romana pertencem a uma produção de luxo, predominando cerâmicas sigillatas hispânicas das oficinas de Andújar e Tricio dos séculos I e II d. C. (fazendo-nos crer que essa foi a época de grande produção mineral de Vipasca). Também foram encontradas ânforas para transporte de azeite do tipo Dressel 20 e também ânforas lusitanas, denotando um decréscimo de produção mineradora na região entre a segunda metade do século III e o século IV. Embora essa domus receba o nome de Casa do Procurador (originado nas primeiras escavações), não há até o momento quaisquer indícios que, de fato, o procurator metallorum (administrador das minas) tenha residido no local. 

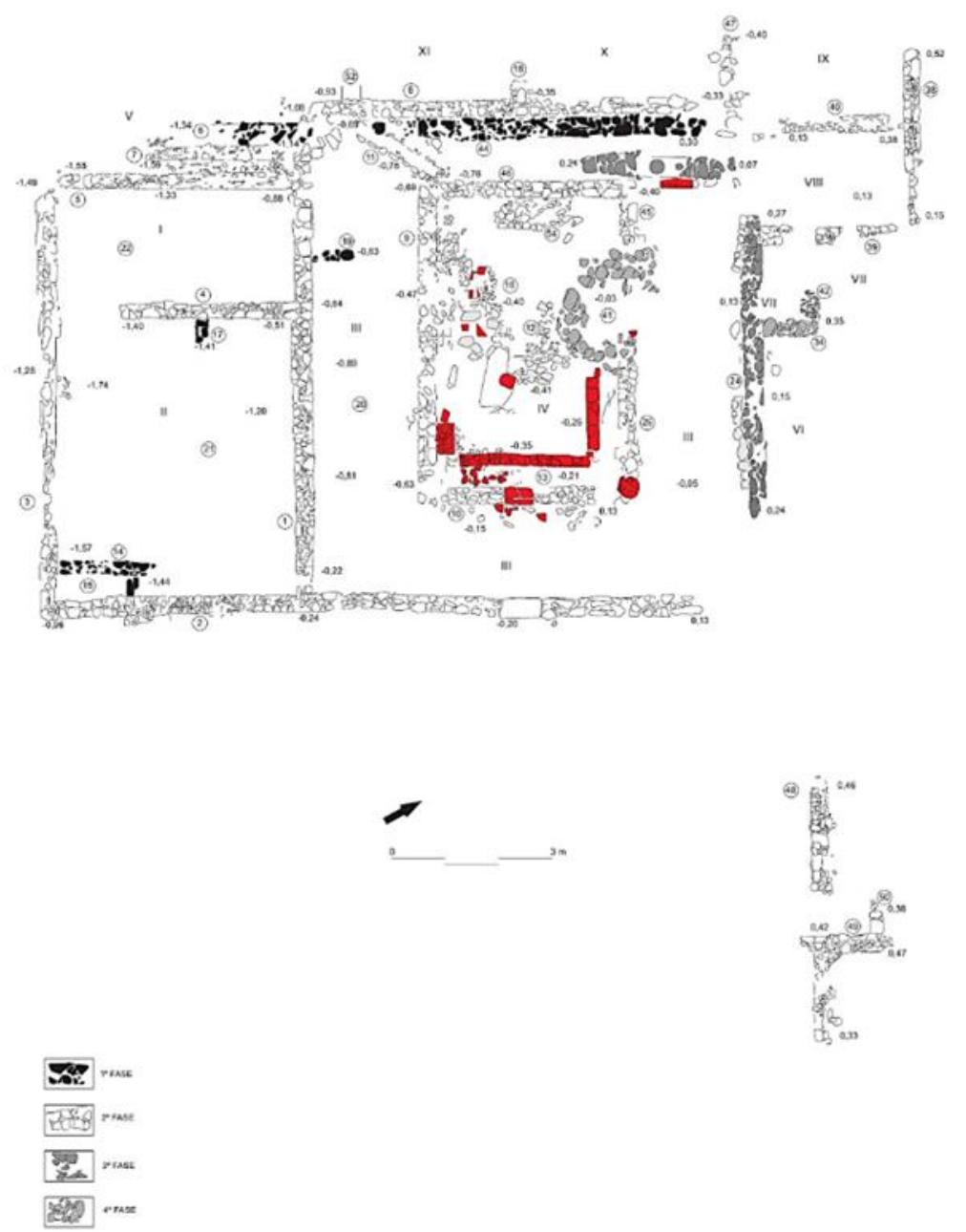

Figura 05: Planta da área escavada da Casa do Procurador mostrando as unidades estratigráficas e as fases de ocupação. Imagem cedida por Artur Martins.

A modelagem 3D, toda feita com o programa Autodesk Maya, baseou-se na planta da área escavada e, os cômodos que não constam na planta, foram hipoteticamente construídos. O modelo final possui 18314 vértices e 16338 faces (totalizando 32728 triângulos), sendo um número adequado a um objeto que está disponível para a visualização em primeira pessoa em um motor gráfico de jogos. Optou-se por uma modelagem o mais simples possível (visando a performance do aplicativo), em que figuras geométricas primitivas foram utilizadas (em sua maioria cubos) para dar o contorno geral da casa. Todos os detalhes foram obtidos por texturização a fim de não sobrecarregar o processamento. A texturização da Casa do Procurador (e da maioria dos objetos presentes no Vipasca Antiga) foi realizada fazendo-se o 
mapeamento UV ${ }^{5}$ do modelo (Fig. 6) e aplicando-se texturas criadas no Photoshop (para os estilos de pinturas nas paredes internas, baseadas em vestígios de Pompeia e Herculano) e substâncias dinâmicas ${ }^{6}$. 0 modelo finalizado (Fig. 7) foi exportado para o Unity no formato proprietário da Autodesk, o FBX.

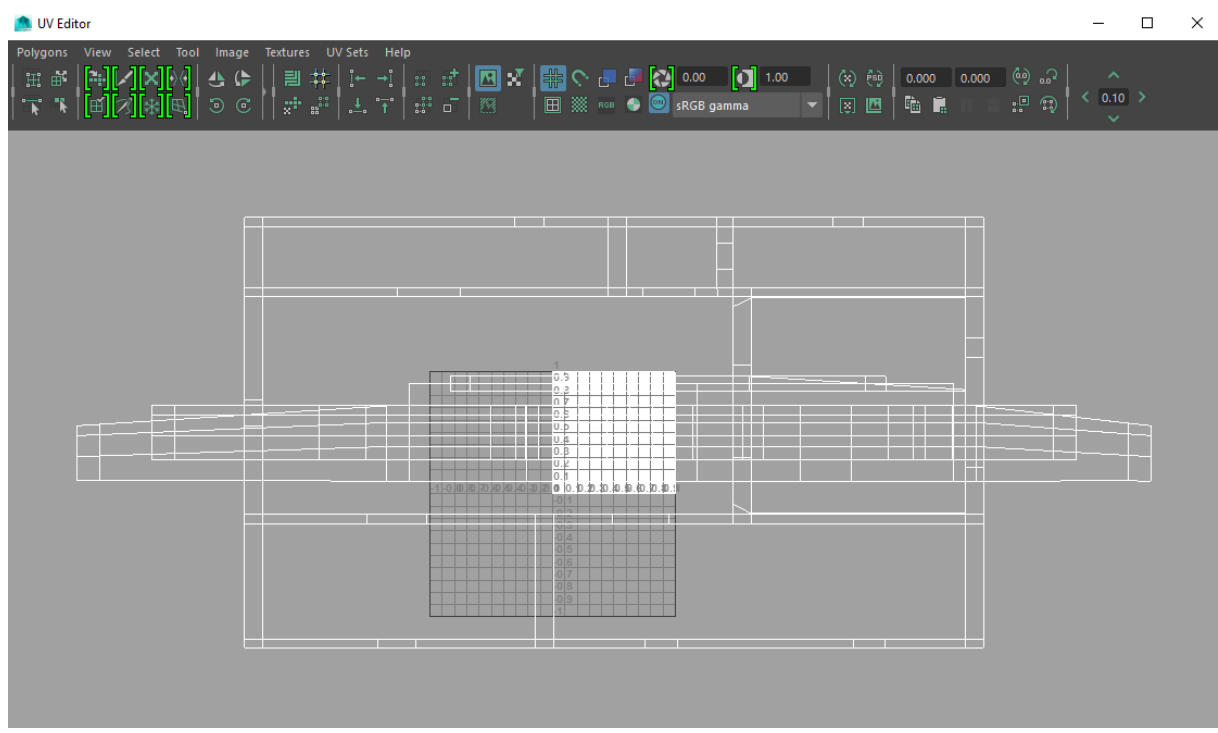

Figura 06: Início do mapeamento UV das paredes exteriores da Casa do Procurador. Captura de tela dentro do programa de modelagem Autodesk Maya.

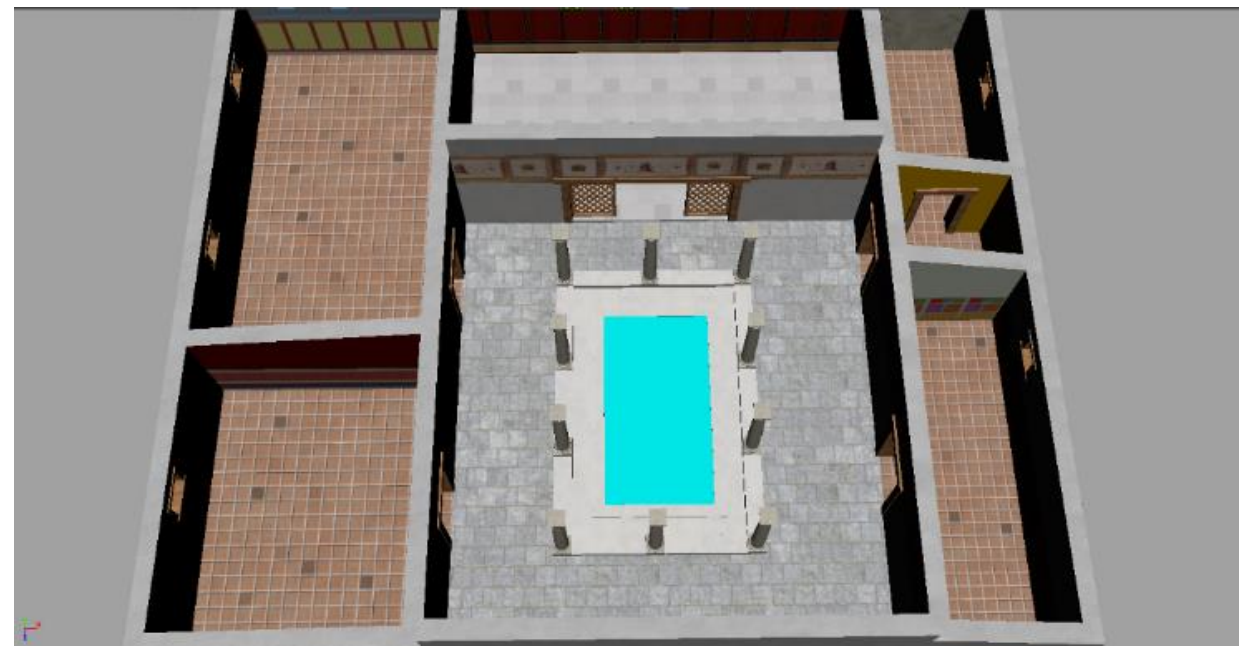

Figura 07: Vista geral da Casa do Procurador finalizada (o suporte do telhado e as telhas foram omitidos nesta visualização). Captura de tela dentro do programa de modelagem Autodesk Maya.

\footnotetext{
${ }^{5} \mathrm{O}$ processo de projetar uma imagem $2 \mathrm{D}$ em um objeto 3D. Simplificando, poderíamos entender como o papel que embrulha um presente. As letras UV correspondem aos eixos $\mathrm{X}$ e $\mathrm{Y}$ da imagem/textura 2D. Mais informações: https://en.wikipedia.org/wiki/UV_mapping (Acesso em 29/03/2017)

${ }^{6}$ Materiais que emulam propriedades físicas de modo convincente, ressaltando elementos como profundidade, desgaste e umidade. As substâncias dinâmicas podem ter suas variáveis modificadas em tempo real dentro de um motor gráfico.
} 


\section{Insulae}

Embora os vestígios arqueológicos de insulae (blocos de apartamentos) na paisagem de Aljustrel sejam escassos, é possível, por meio de sua detecção, afirmar que havia um povoado espalhado por Vipasca ao redor do chapéu de ferro e próximas à ribeira.

As insulae foram modeladas de modo que houvesse uma simplificação ainda maior da malha (mesh) dos objetos tridimensionais a fim de não afetarem demais a performance do aplicativo final. Elas foram divididas em dois grupos: 1) As insulae mais novas (Fig. 8) ficariam em uma área denominada por mim de "Aglomerado Abastado", ou seja, a parte do povoado onde estaria a Casa do Procurador, todas as domus e o fórum - essas insulae contam com texturas de paredes e madeiras mais "limpas', quase novas se comparadas às 2) insulae antigas (Fig. 9): que compõem os demais quatro aglomerados espalhados pela paisagem, que seriam as partes "menos abastadas" de Vipasca, principalmente por uma parte deles ficar na descida da colina, em direção à oficina metalúrgica (área de grande concentração de poluentes).

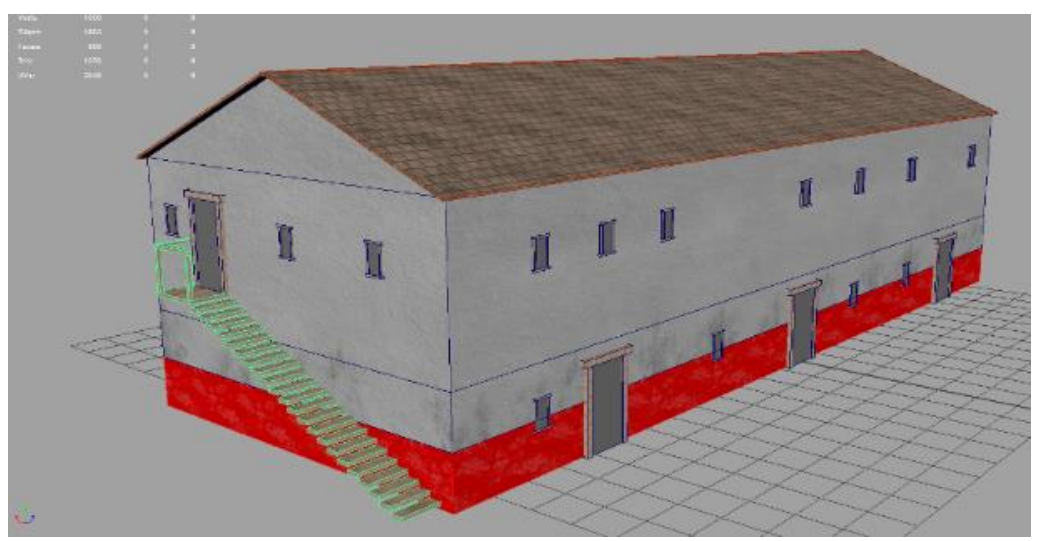

Figura 08: Insula nova. Captura de tela dentro do programa de modelagem Autodesk Maya.

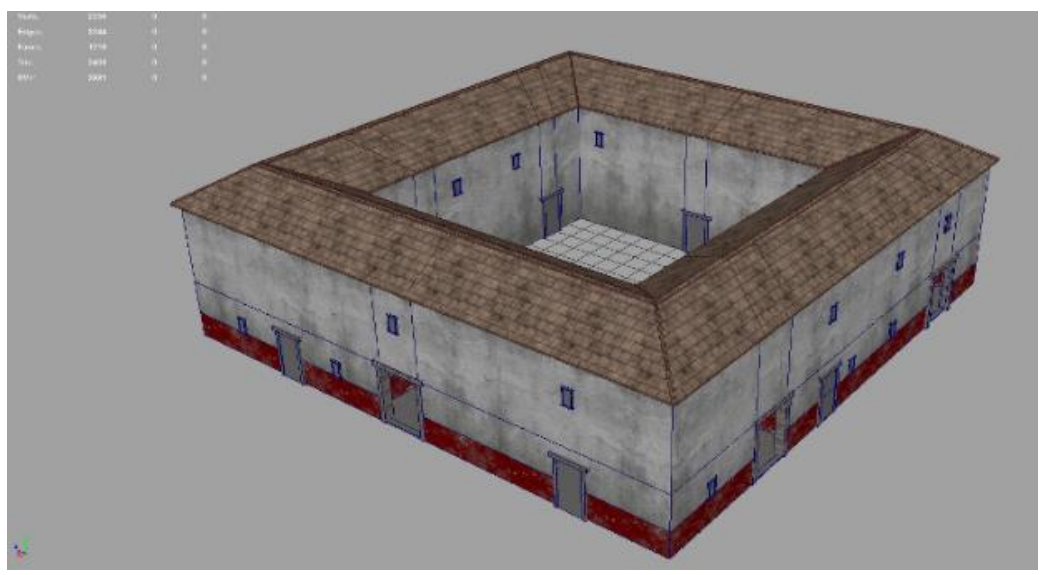

Figura 09: Insula antiga. Captura de tela dentro do programa de modelagem Autodesk Maya.

\section{Oficina Metalúrgica}

A officina aeraria (oficina metalúrgica) localizada na região de Azinhal em Aljustrel, semelhantemente à Casa do Procurador, possui planta definida (da extensão escavada, pois se acredita que 
ela possa ser maior do que aquilo que está exposto). Vestígios de queimas no solo, muros de pedras e pedaços de telhas dão a entender que se trata de um edifício único conhecido até então quando se trata de mineração romana antiga. A oficina possuía uma clara separação entre a parte voltada à queima (céu aberto) e o local de armazenamento de minérios (coberto pelas telhas), conforme podemos ver na planta (Fig. 10). Sua modelagem, ao contrário da maioria dos objetos do aplicativo, foi realizada diretamente no motor gráfico Unity, utilizando-se muros de pedras posicionados de acordo com a planta e depois cobertos com vigas de madeira e telhas (esses, modelados no Autodesk Maya). Modelos tridimensionais de escórias/minérios, lenhas e fogo foram adicionados para formar o conjunto principal (Fig. 11).

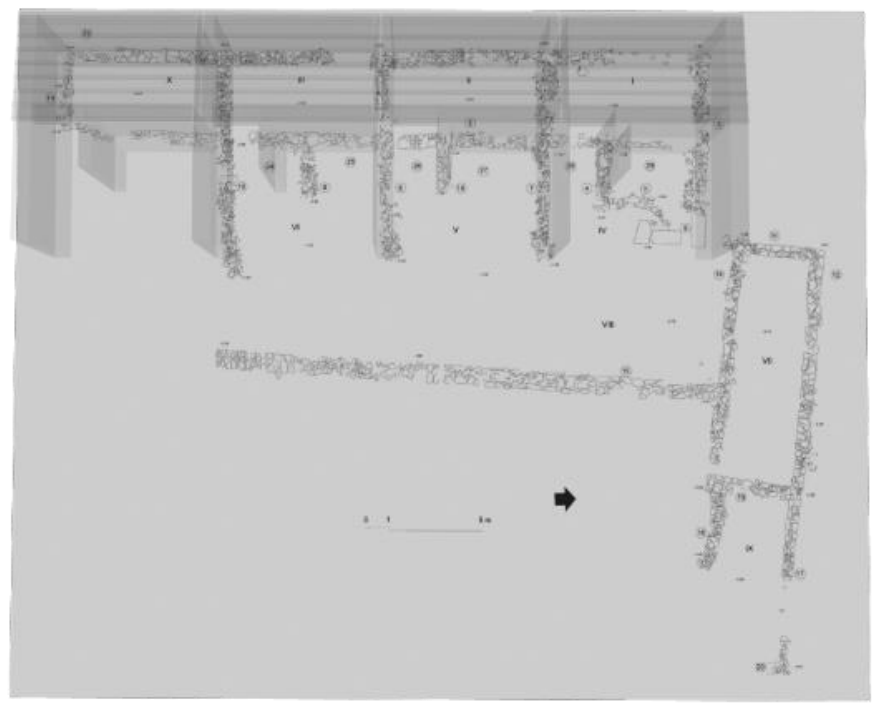

Figura 10: Blocagem (ou seja, o posicionamento de modelos tridimensionais simples - nesse caso, cubos - para fins de escalonamento) dos compartimentos da oficina sobre sua planta (PÉREZ MACÍAS ET AL., 2013, p. 331). Captura de tela dentro do programa de modelagem Autodesk Maya.

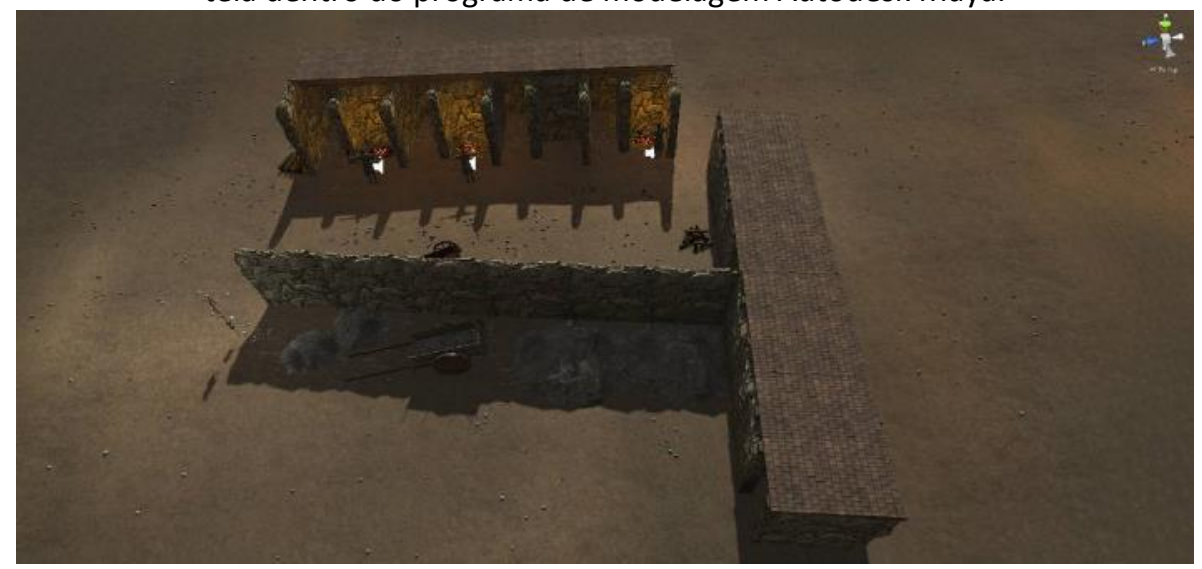

Figura 11: Oficina metalúrgica construída diretamente no Unity. 


\section{Banho/Balneário}

Embora não existam registros sobre vestígios do balneário de Vipasca, ele certamente foi um edifício importante no povoado, uma vez que é mencionado nas chamadas Tábuas de Bronze de Vipasca, que regulamentavam a administração da área mineradora (MARTIRE, 2012, p. 86) - e que constituem, em sua descoberta pela paisagem, o objetivo principal do aplicativo Vipasca Antiga:

A primeira placa foi encontrada em maio de 1876 durante os trabalhos efetuados pela Companhia de Mineração Transtagana em escoriais romanos abandonados. Comumente conhecida por Lex Metallis Vipascensis, ou LMV, a tábua tem $78,5 \mathrm{~cm}$ de altura por $52 \mathrm{~cm}$ de largura e possui espessura variando entre 8 e $13 \mathrm{~mm}$. Seu lado direito foi cortado no sentido da altura e possui inscrições frente e verso, invertidas. Apesar de primeiramente ter sido denominada "Tábula de Bronze de Aljustrel" por Álvaro d'Ors quando foi encontrada, a placa não é feita com esse material, uma vez que não há estanho em sua composição, ao contrário, foi produzida com cobre impuro proveniente da região de Aljustrel. Esse tipo de produção em cobre e chumbo fora mencionado por Plínio (XXXIII, 20). A segunda tábua, a Lex Metallis Dicta - ou LMD - foi achada entre escoriais romanos abandonados em 1906 pela empresa concessionária das minas de Aljustrel Sociétè Anonyme Belge des Mines d'Aljustrel. Ela possui $77 \mathrm{~cm}$ de altura por 55 $\mathrm{cm}$ de largura e $10 \mathrm{~mm}$ de espessura, também feita em cobre impuro, não bronze. Diferentemente da LMV, a LMD pode ser datada entre os anos 117 a 138 d.C., uma vez que existe alusão ao imperador Adriano.

$\mathrm{Na}$ ausência de vestígios locais do edifício, o balneário foi inteiramente modelado "genericamente", contendo os principais elementos dos banhos no período entre os séculos I e II d. C., a saber: o frigidarium (sala com piscina de água fria), o tepidarium (sala de vapor, sendo uma transição espacial entre o frigidário e o caldário), o caldarium (sala com piscina de água quente em tamanho menor do que o frigidário) e o peristilo (jardim colunado para simples caminhar ou praticar exercícios físicos). 0 modelo do balneário finalizado (Fig. 12) foi posto às margens da Ribeira de Feitais como hipótese de facilitação de escoamento das águas das piscinas quando necessário.

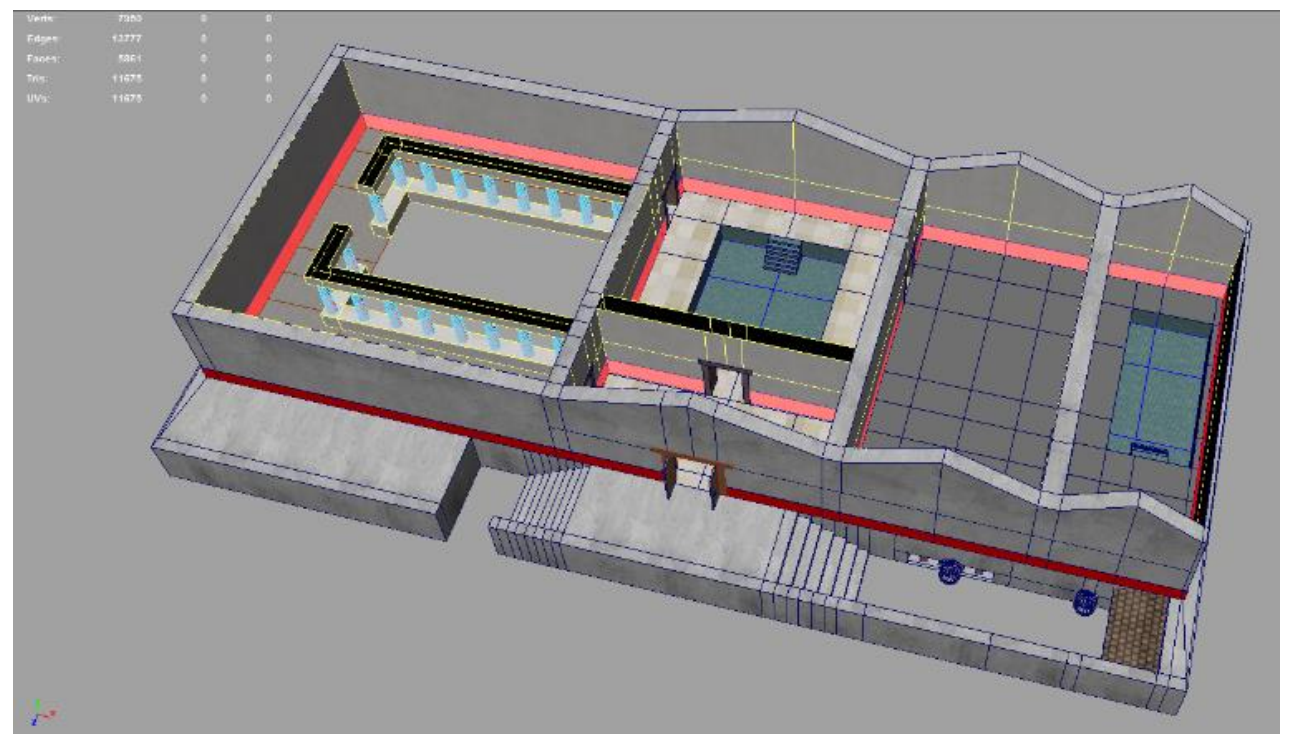

Figura 12: Balneário: o frigidário está logo após a porta de entrada do edifício, o tepidário é a sala intermediária entre 
o frigidário e o caldário (local com a menor piscina); as colunas formam o peristilo. Captura de tela dentro do programa de modelagem Autodesk Maya.

\section{Galerias de Mineração}

As galerias de extração mineral serviam para escoamento da produção existente nas grandes montanhas de minérios e foram modeladas a partir dos exemplos existentes em Trêsminas (Vila Pouca de Aguiar, Portugal) (Figs. 13-14).

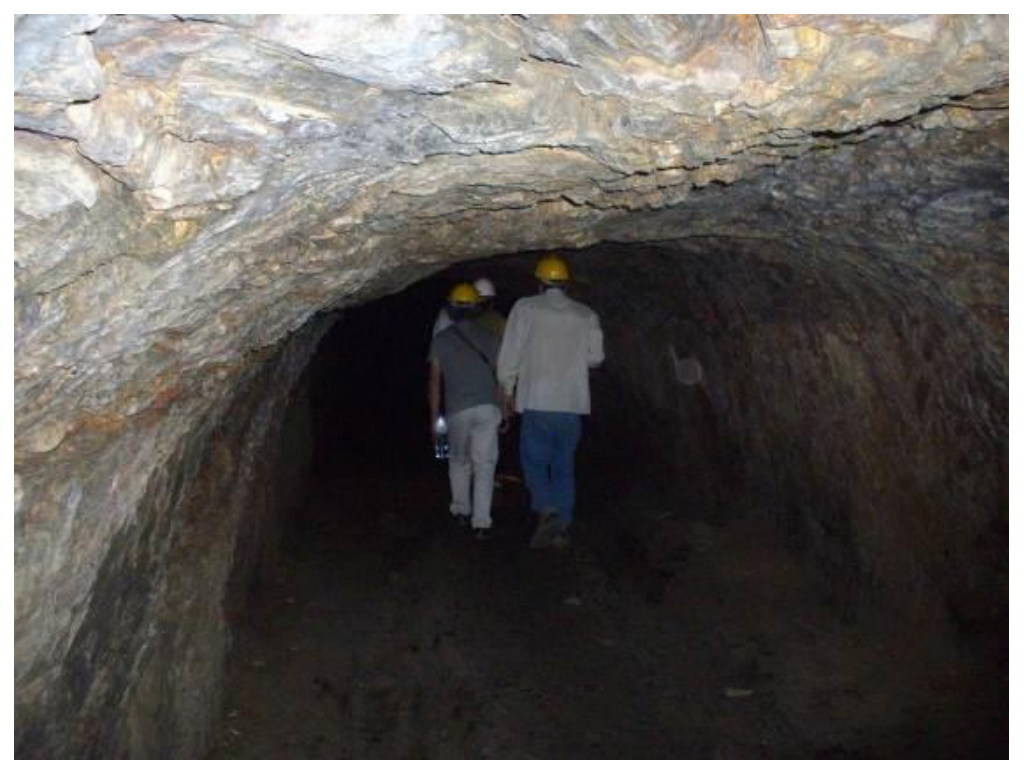

Figura 13: Galeria dos Alargamentos, Trêsminas. Vila Pouca de Aguiar, 2010. A galeria tem $140 \mathrm{~m}$ de comprimento por $2 \mathrm{~m}$ de largura e 1,5 $\mathrm{m}$ de altura (tendo sido aberta a $50 \mathrm{~m}$ abaixo do topo da exploração). Recebe esse nome devido a quatro alargamentos que permitiam a passagem de carros de transporte nos dois sentidos que alcançavam as estradas para levar o material à lavagem e trituração.

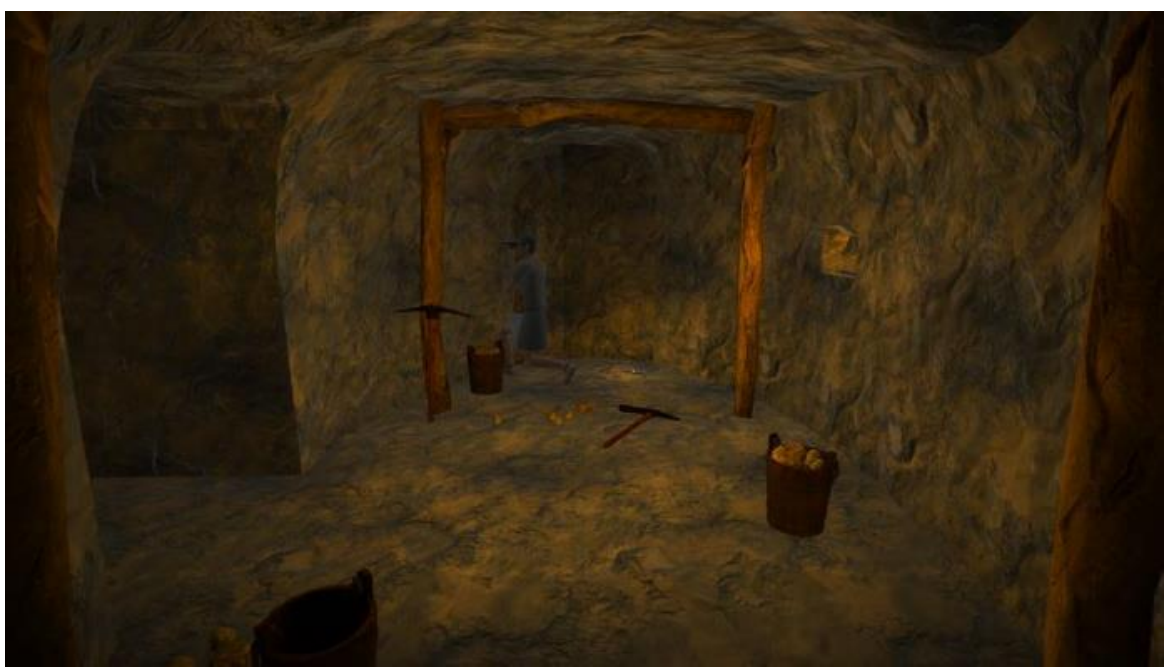

Figura 14: Galeria de extração mineral dentro do aplicativo Vipasca Antiga. 


\section{Pessoas}

Foram utilizados dois modelos básicos de pessoas para o aplicativo, um homem e uma mulher, com a cor de suas roupas e cabelos variando.

Para a animação dos personagens, como caminhar, gesticular, exercer alguma ação etc., a ferramenta online Mixamo foi usada. Pertencendo à empresa Adobe, ela permite "rigar" (ou seja, inserir um esqueleto digital articulado) qualquer modelo automaticamente, apenas posicionando sobre ele as junções principais do corpo (joelhos, cotovelos, pescoço etc.). Depois, basta escolher as animações que deseja aplicar ao modelo e editar suas características básicas (velocidade, altura/distância dos braços, temperamento etc.), salvando todo o pacote de animações e modelo "rigado" em formato .FBX para Unity (Fig. 15). No total, 34 animações masculinas e 10 animações femininas foram editadas no Mixamo e aplicadas aos personagens no aplicativo Vipasca Antiga.

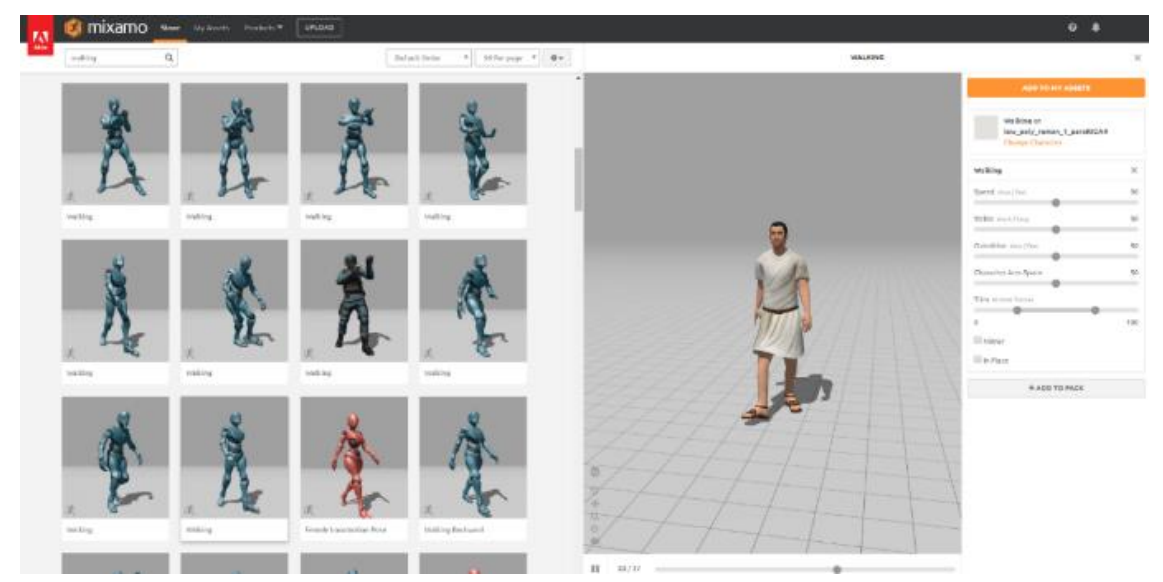

Figura 15: Interface da plataforma Adobe Mixamo.

\section{Programação / Interatividade}

A interatividade é o que fará com que o aplicativo ciberarqueológico seja diferente de uma animação 3D. A programação é responsável por fazer o diálogo entre o usuário e a máquina, auxiliando no processo cognitivo estabelecido no aplicativo. Por este ser um artigo, não é possível pormenorizar todo o processo de programação de Vipasca Antiga, que levou quase nove meses para ser finalizado. Assim sendo, irei apenas discorrer sobre aquilo que acredito serem os pontos principais, as quests (missões) e os diálogos.

Vipasca era um povoado grande e isto é refletido no ambiente virtual tridimensional. Embora no aplicativo exista a opção de simples navegação pelo território, a experiência de Vipasca Antiga foi pensada a fim de que suas missões sejam trabalhadas. Existiria uma chance muito grande de desinteresse por parte dos usuários caso eles apenas navegassem entre edifícios e pessoas, sem terem um porquê, deixando de explorar áreas que são importantes do ponto de vista histórico e arqueológico. Desse modo, ficou 
estabelecido que encontrar as Tábuas de Bronze perdidas por Vipasca seria a quest principal do aplicativo, iniciando-se quando o usuário adentra a Casa do Procurador e conversa com o procurator metallorum, que o incumbe de recolher as tábuas espalhadas pelo território a fim de receber como prêmio o certificado de arrendatário das minas (e o direito de visitar as galerias subterrâneas de exploração mineral).

As quests foram desenvolvidas dentro do editor do Dialogue System, um plugin que funciona com o motor gráfico Unity. Uma linha de programação em linguagem Lua - que depois teve a sua variante de contagem inserida como script em cada Tábua a ser encontrada - foi suficiente para estabelecer o corpo da missão principal, a saber: [lua(Variable[“Tábuas"])] de sete encontradas (Fig. 16). A segunda missão, a de encontrar o mineiro para ganhar acesso às galerias, sequer precisou de linhas adicionais de programação, demonstrando a facilidade de uso da ferramenta Dialogue System por quem não é programador.

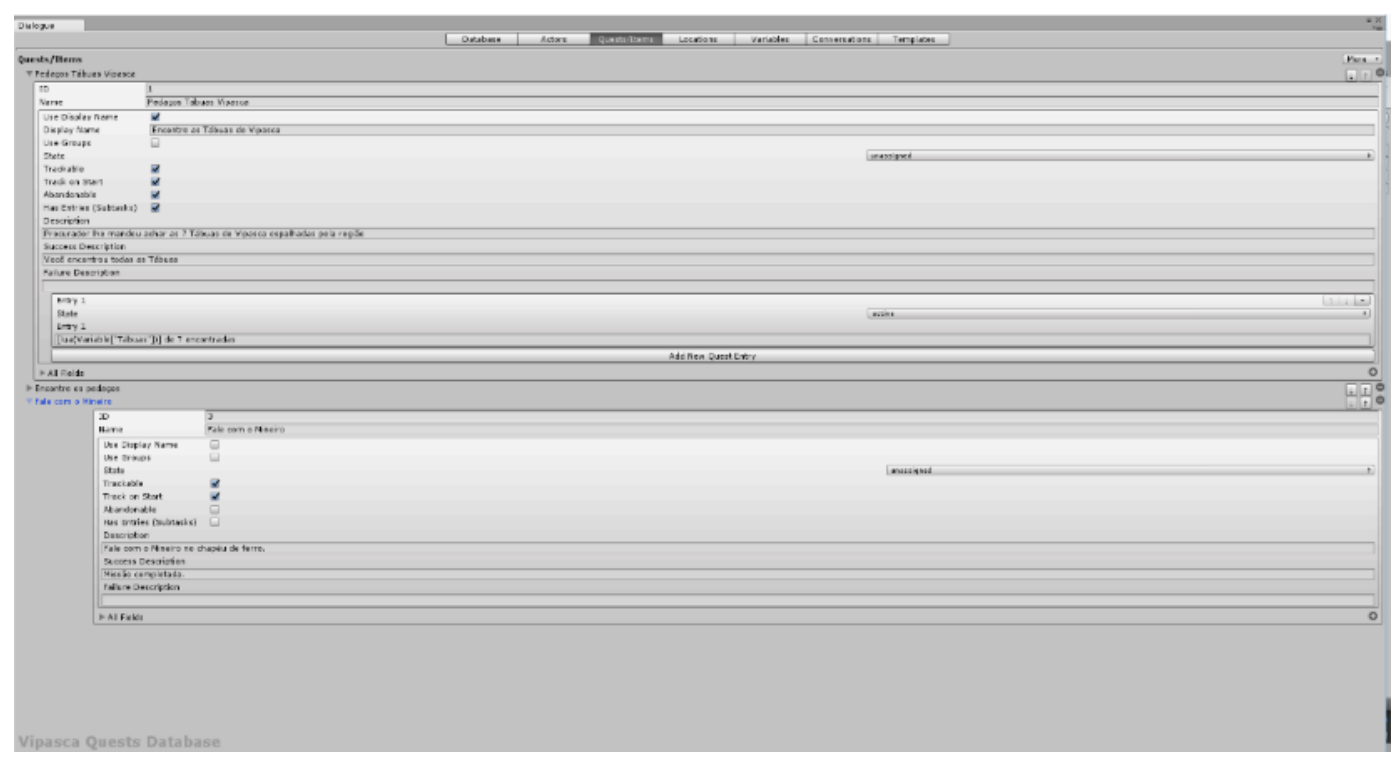

Figura 16: Tela de edição das quests no Dialogue System. Captura de tela dentro do motor gráfico Unity.

Finalizado o sistema principal de missões, começou a escrita dos diálogos. Dentre os 266 NPCs (Non-Player character, personagem não jogável) existentes no aplicativo, 78 foram escolhidos como atores, ou seja, personagens aptos a emitirem caixas de diálogo na tela. E dentre os 78 atores, 22 deles possuem diálogos interativos (aquele em que o NPC dispara um texto e o jogador tem a opção de escolher uma dentre várias respostas para dar continuidade à conversa) e 56 possuem diálogos engatilhados (linhas de texto que aparecem sobre a cabeça do NPC que está falando no momento) (Figs. 17-18). Somando-se os diálogos interativos e os engatilhados, foram escritas 596 caixas de texto para o aplicativo Vipasca Antiga. 


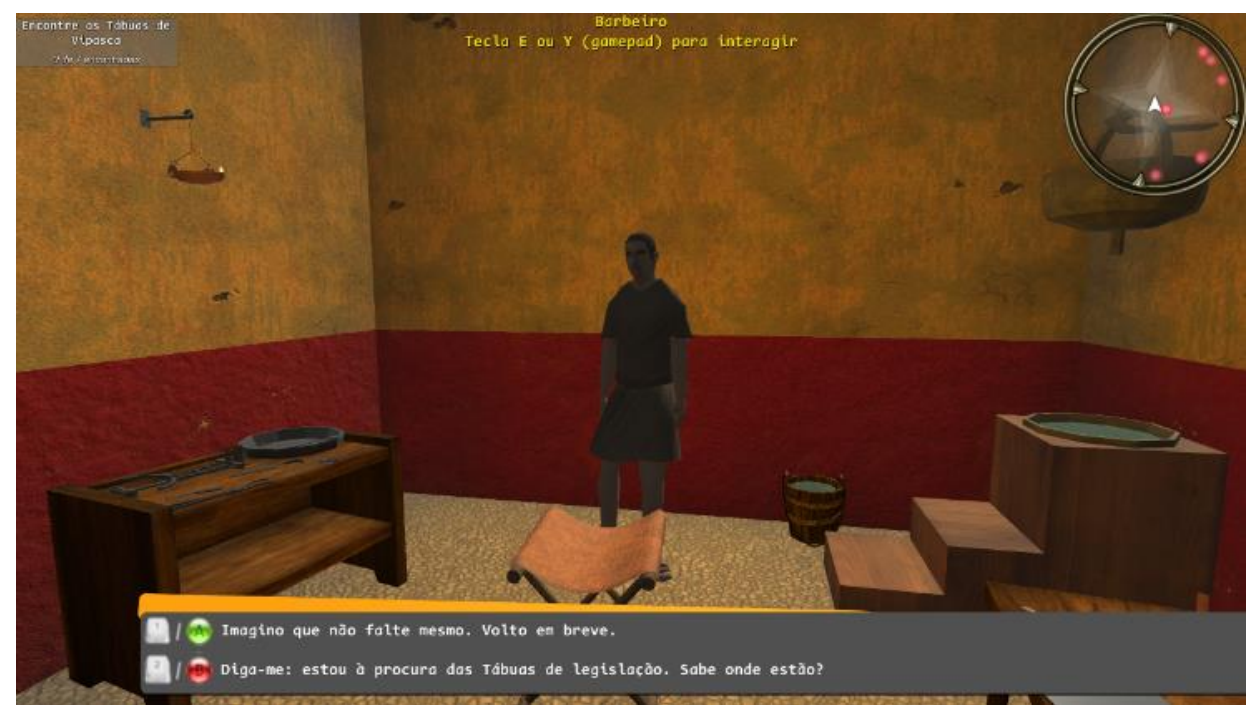

Figura 17: Sistema de respostas no diálogo interativo. Captura de tela dentro do aplicativo Vipasca Antiga.

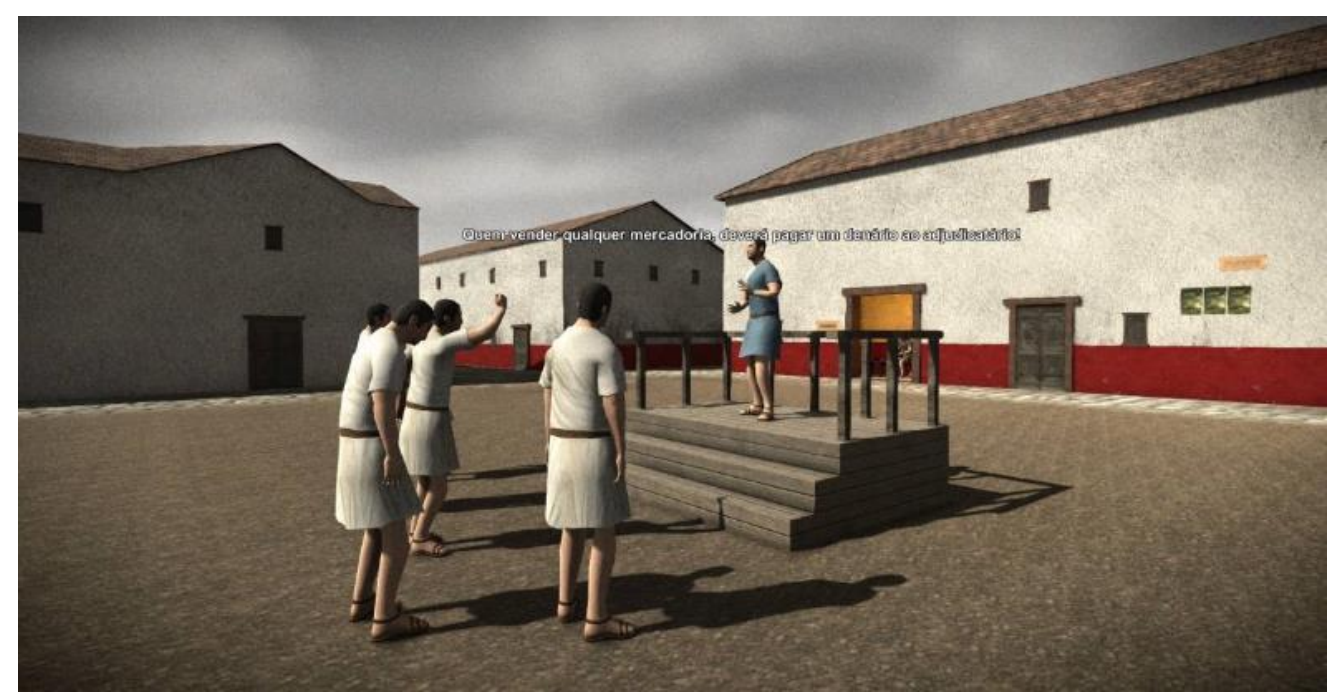

Figura 18: Diálogo engatilhado sobre a cabeça do pregoeiro no fórum. Captura de tela dentro do aplicativo Vipasca Antiga.

\section{CONCLUSÃO}

A extensão deste artigo, creio, denote um pouco a complexidade envolvida na Ciberarqueologia. É uma área que atua na interseção entre Filosofia, Engenharia e Arqueologia e, por isso mesmo, creio que sua definição é um tanto elástica e irá variar conforme a produção tecnológica se desenvolva. Com certeza, dispositivos eletrônicos que neste exato momento são caros ou ainda estão em fase de prototipagem, em pouco tempo farão parte de nosso cotidiano. Óculos de Realidade Aumentada já estão no mercado (por exemplo, Microsoft HoloLens) mas, por enquanto, o valor unitário é proibitivo para muitas instituições de pesquisa e usuários finais. Não duvido, no entanto, que brevemente serão uma tecnologia cotidiana e, mais do que isso, serão fundamentais no desenvolvimento ciberarqueológico, afinal, misturar o mundo que 
vemos ao vivo com informações computacionais trará novidades ao campo arqueológico, permitindo que os pesquisadores vejam, por exemplo, todas as etapas de escavação anteriores no próprio sítio, em tempo real.

Como vimos, a Ciberarqueologia é a união entre cibernética e arqueologia. Da cibernética, emprestamos definições oriundas das três ondas de pesquisas que permearam seu desenvolvimento como campo de estudo: temos interação em tempo real e imersão nos aplicativos ciberarqueológico - você caminha pela paisagem de Vipasca Antiga, você conversa com as pessoas, você cumpre o objetivo de encontrar as Tábuas, e você decide quais textos informativos deseja ler ou quais fotogrametrias deseja observar: o controle é totalmente seu, e a sua interatividade irá ditar o ritmo de navegação pelo aplicativo e, assim espero, o de aprendizado também. Desse modo, a cibernética de Wiener, de Maturana, de Langton e de Turing está presente na construção de um aplicativo ciberarqueológico: se você não consegue interagir com um modelo em tempo real, isso não é Ciberarqueologia, é Arqueologia Virtual (ou seja, passiva). Da arqueologia, emprestamos toda a tradição que está ligada à disciplina desde o HistóricoCulturalismo do início do século XX: ainda vamos a campo e escavamos, e depois levamos materiais para os laboratórios e os analisamos. Contudo, a rotina atual é bastante influenciada pelo uso de computadores, indo desde o estudo de mapas gerados por satélites digitais espaciais até o escaneamento tridimensional de quadras arqueológicas ou a fotogrametria de elementos-chave presentes na escavação. A arqueologia do século XXI, embora ainda contando com métodos analógicos (ou seja, sem uso de computadores), cada vez mais tem se apropriado de meios digitais: isso não apenas facilita o trabalho do arqueólogo em campo (por exemplo, na rapidez de coleta de dados), como também permite que análises possam ser feitas em laboratórios a partir de modelos digitais, muitas vezes permitindo a descoberta de dados que não foram possíveis de serem identificados durante a escavação por motivos específicos.

O aplicativo Vipasca Antiga é ciberarqueológico porque estabelece o diálogo entre cibernética e arqueologia. Toda a base do aplicativo está centrada em estudos de escavações anteriores realizadas no local, bem como observações diretas minhas e trabalhos fotogramétricos que fiz em Aljustrel. A paisagem mineradora arqueológica é uma das mais complexas de serem estudadas, pois mineração é uma atividade essencialmente destrutiva: a arqueologia da mineração é o estudo, a partir da destruição (pois a arqueologia ainda assim se comporta), daquilo que as sociedades do passado destruíram para obter seus minérios... Aquilo que chega até nós são meros fragmentos e nos força a criar muitas hipóteses de reconstituição de paisagem. Exatamente nesse ponto é que entra a cibernética na arqueologia: com ela, podemos testar, em tempo real, nossas ideias sobre o passado. Vipasca Antiga é uma grande hipótese de trabalho: os elementos que o usuário vê e com os quais interage atualmente são fragmentos do passado romano e tiveram de ser reconstituídos tridimensionalmente. A Ciberarqueologia, assim, apresenta-se 
como um verdadeiro estudo de um passado em potencial, de um passado "que poderia ter sido tal como reconstituído em 3D".

Se fui feliz em minhas conceituações, você agora conhece um pouco mais desse ramo recente da arqueologia. A cibernética, como demonstrei, está intrinsicamente ligada à ideia ciberarqueológica: a relação homem-máquina existe e está absurdamente presente em nossas vidas atualmente (basta lembrar que estamos sempre com nossos smartphones em mãos, não no bolso - ou seja, nossa relação com o dispositivo é praticamente simbiótica). E graças à cibernética temos a possibilidade de interagir com passados em potencial (ie. virtuais) em tempo real, gerando dados informativos que são processados pelos computadores e retornados a nós em forma de resposta em tela.

Desse modo, espero que a leitura não tenha repelido você, mas, sim, despertado a curiosidade por esse fascinante mundo cibernético arqueológico. Creio que já me estendi demais: agora é a sua vez de experimentar o aplicativo Vipasca Antiga. Boa viagem ao passado! 


\section{REFERÊNCIAS BIBLIOGRÁFICAS}

FORTE, Maurizio (ed.). Cyber-Archaeology. BAR, v. 2177, Oxford: Archaeopress, 2010.

HAYLES, N. Katherine. How we became posthuman. Virtual bodies in cybernetics, literature, and informatics. Chicago: The University of Chicago Press, 1999.

LANGTON, Christopher G. (ed.). Artificial life. The proceedings of an interdisciplinary workshop on the synthesis and simulation of living systems (Los Alamos, New Mexico, September 1987), v. 6. Boston: Addison-Wesley Publishing Company, 1988.

LÉVY, Pierre. O que é o virtual? Tradução: Paulo Neves. São Paulo: Editora 34, 2007.

MARTIRE, Alex da S. Arqueologia da paisagem mineira romana: a Hispânia e a Lusitânia. (Dissertação de Mestrado) Museu de Arqueologia e Etnologia, Universidade de São Paulo, São Paulo, 2012.

MARTIRE, Alex da S. Ciberarqueologia em Vipasca: o uso de tecnologias para a reconstrução-simulação interativa arqueológica. (Tese de Doutorado) Museu de Arqueologia e Etnologia, Universidade de São Paulo, São Paulo, 2017.

MATURANA, Humberto R.; VARELA, Francisco J. A árvore do conhecimento. As bases biológicas da compreensão humana. Tradução: Tradução: Humberto Mariotti e Lia Diskin. São Paulo: Editora Palas Athena, 2011.

NORVIG, Peter; RUSSEL, Stuart. Inteligência Artificial [Ebook Kindle]. Tradução: Regina Célia Simille. Rio de Janeiro: Editora Campus-Elsevier, 2014.

PÉREZ MACÍAS, Juan A. et al. In ábditas terras. Investigações arqueológicas em Aljustrel. Huelva: Ediciones Consulcom, 2013.

REILLY, Paul. Towards a virtual archaeology. In: LOCKYEAR, Kris; RAHTZ, Sebastian (eds.). Computer Applications in Archaeology 1990. Oxford: British Archaeological Reports (Int. Series 565), 1990, p. 133-139.

WIENER, Norbert. Cibernética e sociedade: o uso humano de seres humanos. Tradução: José Paulo Paes. São Paulo: Cultrix, 1968. 